\title{
Pengembangan perangkat pembelajaran matematika problem posing tipe post solution posing pada materi statistika
}

\author{
Vanny Algafari ${ }^{*}$, Nyoman Sridana ${ }^{2}$, Muh Turmuzi ${ }^{2}$, Sripatmi $^{2}$ \\ ${ }^{1}$ Mahasiswa Pendidikan Matematika, FKIP, Universitas Mataram, Mataram \\ ${ }_{2}^{2}$ Pendidikan Matematika, FKIP, Universitas Mataram, Mataram
}

algaf9962@gmail.com

Diterima: 11 Juni 2021; Direvisi: 23 Juni 2021; Dipublikasi: 30 Juni 2021

\begin{abstract}
The purpose of this research was to obtain a practical Problem Posing type of Post Solution Posing learning tool according to the Mathematics teacher at SMPN 1 Batulayar. This type of research is qualitative research by giving questionnaires and interviews. The subjects in this study were the Mathematics Teachers at SMPN 1 Batulayar. The object of this research is the practicality of the learning tools, namely the Learning Implementation Plan and Student Worksheets with the post solution posing problem posing type model. The instruments used in this study were questionnaires and interviews. The questionnaire made is a structured questionnaire with answers that are not free and has been validated. Interviews were conducted in a structured manner according to understanding. Based on the results of the analysis in this study, it shows that the learning tools for the post solution posing model are very practical and easy to apply.
\end{abstract}

Keywords: Practical; Problem Posing; Post Solution Posing; Easy to Apply

\begin{abstract}
Abstrak
Tujuan peneitian ini adalah untuk memperoleh perangkat pembelajaran Problem Posing Tipe Post Solution Posing yang praktis menurut guru Matematika di SMPN 1 Batulayar. Jenis penelitian yang digunakan adalah penelitian kualitatif dengan pemberian angket dan wawancara. Subyek dalam penelitian ini adalah Guru Matematika di SMPN 1 Batulayar. Obyek dalam penelitian ini adalah kepraktisan perangkat pembelajaran yakni Rencana Pelaksanaan Pembelajaran (RPP) dan Lembar Kerja Peserta Didik (LKPD) dengan model problem posing tipe post solution posing. Instrumen yang digunakan dalam penelitian ini berupa angket dan wawancara. Angket yang dibuat merupakan angket berstruktur dengan jawaban tidak bebas dan sudah di Validasi. Wawancara yang dilakukan berstruktur sesuai dengan pemahaman. Berdasarkan hasil analisis dalam penelitian ini menujukan bahwa perangkat pembelajaran model posing post solution posing sangatlah praktis dan mudah diterapkan.
\end{abstract}

Kata Kunci: Praktis; Problem Posing; Post Solution Posing; Mudah Diterapkan

\section{PENDAHULUAN}

Matematika adalah ilmu pengetahuan yang abstrak, yang diperoleh dengan bernalar dan berbentuk simbol. Matematika tidak hanya sekedar kemampuan cepat dalam berhitung namun matematika membutuhkan konsep yang teratur dan sistimatis, mulai dari konsep yang paling sederhana sampai pada konsep yang paling kompleks (Suherman, 2003) 
Matematika mempelajari tentang pola keteraturan, tentang struktur yang terorganisasikan, hal itu dimulai dari unsur-unsur yang tidak terdefinisikan, kemudian pada unsur yang didefinisikan, ke aksioma/postulat, dan akhirnya pada teorema." Sehingga siswa mudah mengerti maksud matematika, mampu bernalar dan dapat memecahkan masalah dengan berbagai cara (Ruseffendi, 1980).

Matematika merupakan salah satu mata pelajaran yang dijadikan syarat kelulusan, sehingga menjadi salah satu mata pelajaran yang wajib dikuasai oleh siswa. Meskipun demikian pada kenyataannya masih banyak siswa yang kesulitan dalam memahami pelajaran Matematika. Keadaan serupa ternyata juga terjadi di SMP Negeri 1 Batulayar, dimana kemampuan matematika siswa kelas VIII masih rendah. Hal ini terlihat dari nilai ulangan tengah semester (UTS) mata pelajaran matematika pada semester ganjil tahun pelajaran 2019/2020 masih banyak nilai siswa di bawah KKM yang ditetapkan sekolah yakni 70. Untuk lebih jelasnya dapat dilihat pada tabel berikut.

Tabel 1.1. Data Hasil Ujian Tengah Semester Ganjil Siswa Kelas VIII di SMPN Negeri 1 Batulayar Tahun Pelajaran 2019/2020

\begin{tabular}{cccc}
\hline No & Kelas & Jumlah Siswa & Nilai Rata-Rata \\
\hline 1 & VIII A & 21 & 65,4 \\
2 & VIII B & 22 & 66,3 \\
3 & VIII C & 22 & 61,4 \\
\hline \multicolumn{2}{l}{ (Sumber: Daftar Nilai Guru Matematika Kelas VIII SMP Negeri 1 Batulayar) }
\end{tabular}

Berdasarkan data tersebut, masih banyak siswa yang belum mencapai Kriteria Ketuntasan Minimum (KKM) yaitu 70. Hal ini dapat membuktikan rendahnya prestasi belajar matematika kelas VIII SMP Negeri 1 Batulayar. Hal-hal tersebut disebabkan antara lain, kurangnya belajar siswa khususnya dalam pembelajaran matematika, banyak siswa yang beranggapan bahwa pelajaran matematika pelajaran yang sulit dan sangat membosankan, rata-rata siswa jarang melakukan latihan soal baik di sekolah maupun di rumah. Oleh karena itu dibutuhkan perangkat pembelajaran yang praktis dan tidak membosankan bagi siswa. Salah satu perangkat pembelajaran yang dimaksud adalah perangkat pembelajaran yang menerapkan model pembelajaran problem posing tipe post solution posing. Problem posing merupakan model pembelajaran yang mengharuskan siswa menyusun pertanyaan sendiri atau memecah suatu soal menjadi pertanyaan-pertanyaan yang lebih sederhana. Selain siswa menyusun pertanyaan, siswa juga harus mampu menyelsaikan pertanyaan yang telah dibuat dengan jawaban yang divergen (Shoimin, 2014).

Bedasarkan pengertian di atas dapat dipahami bahwa model pembelajaran problem posing dapat mengatasi kebosanan siswa dalam menerima materi pelajaran. Selain itu guru juga tidak dipersulit dalam menyiapkan perangkat pembelajaran dengan biaya mahal dan sulit didapatkan. 
Keberadaan model pembelajaran yang praktis seperti halnya model problem posing tipe post solution posing kurang dimendapatkan perhatian dan jarang diterapkan oleh guru matematika di bagai jenjang pendidikan termasuk di SMP Negeri 1 Batulayar.

SMP Negeri 1 Batulayar merupakan merupakan sekolah yang terletak di kabupaten Lombok Barat yang ada diwilayah kawasan wisata. Disekolah tersebut terdapat dua guru matematika yang berstatus ASN. Dalam pembelajaran mereka umumnya mengawali dengan memberikan penjelasan kemudian memberikan soal latihan dalam hal tersebut siswa hanya sekadar dilatih untuk menjawab soal yang dibuat oleh guru dengan jenis soal yang sama untuk semua siswa. Hal tersebut tentunya dapat dipahami mengingat guru akan kesulita untuk membuat soal yang berberda untuk setiap siswa. Namun demikian berbeda halnya jika siswa tidak sekedar berlatih menjawab soal yang dibuat oleh guru akan tetapi setiap siswa juga dilatih untuk membuat soal sendiri sehingga di mungkinkan setiap siswa memiliki soal yang berbeda-beda tampa dibuatkan oleh guru. Artinya guru tidak direpotkan untuk membuat soal yang berbeda-beda untuk setiap siswa. Dengan demikan, model problem posing tipe post solution posing sangatlah praktis. Miskipun demikian, tentunya setiap guru memiliki penilanyaan tersendiri terkait kepraktisan suatu model pembelajaran tertentu. Oleh karena itu peneliti tertarik melakuakan penelitian guna mengetahui pendapat guru matematika tentang kepraktisan dari model pembelajaan problem posing tipe post solution posing di SMP Negeri 1 Batulayar.

\section{METODE}

Jenis penelitian ini adalah penelitian kualitatif dengan cara melakukan observasi peroses pembelajaran dan pemberian angket kepada guru serta malakukan wawancara dengan guru.Desain penelitian ini menggunakan instrumen berupa angket dan wawancara. Angket adalah tehnik pengumpulan data yang dilakukan dengan cara memberi seperangkat pertanyaan atau pernyataan tertulis kepada responden untuk dijawabnya. Metode yang dilakuakan dengan cara mengumpulkan data berdasarkan informasi atau keteranrangan dari hasil pengamatan selama proses penelitian berlangsung. Sebelum pemberain angket, angket terlebih dahulu di validasi oleh validator. Tujuannya untuk mengetahui kevaliditasan dari angket tersebut. Subyek dalam Penelitian adalah Guru Matematika di SMPN 1 Batulayar berjumlah 2 orang.Obyek dalam penelitian ini adalah kepraktisan perangkat pembelajaran yakni Rencana Pelaksanaan Pembelajaran (RPP) dengan model problem posing tipe post solution posing. Teknik pengumpulan data dalam penelitian ini adalah pemberian angket dan wawancara.

Instrumen yang digunakan dalam penelitian ini berupa lembar angket dan wawancara. Dalam uji validitas Instrumen terdapat dua dosen ahli Matematika yang memvalidasi 
instrumen penelitian. Berdasarkan uji validitas yang teelah dilakukan didapatkan hasil bahwa Instrumen layak digunakan (valid). Teknik analisis data akan dilakuakan secara bertahap yakni pertama memberikan angket kepada guru kedua melakukan wawancara dengan guru. Dalam analisis hasil angket, peneliti menggunakan sekala likert sebagai alat ukur jawaban dari suatu pertanyaan pada indikator yang sudah ditentukan secara spesifik. Selanjutnya peneliti menjumlahkan seluruh sekor yag sudah diakumulasi dengan banyak penjawab pada suatu pertanyaan. Berdasarkan jumlah skor yang diperoleh dibagi dengan jumlah skor ideal untuk memperoleh rata-rata. Hasil rata-rata yang diperoleh dikali $100 \%$ untuk menentukan persentase tingkat persetujuan. Berikut rumus:

$$
\begin{aligned}
& \text { rata }- \text { rata skor }=\frac{\text { jumlah skor }}{\text { banyak penjawab }} \\
& \text { pesentase }=\frac{\text { rata }- \text { rata skor }}{\text { skor ideal }} \times 100 \%
\end{aligned}
$$

Jika persentasenya diperoleh 50\% maka dapat dikatakan bahwa perangkat pembelajaran dalam hal ini RPP dan LKPD sangtlah praktis. Sebaliknya jika persentase di peroleh kurang dari 50\% maka dapat dikatakan bahwa perangkat pembelajaran dalam hal ini RPP dan LKPD tidak praktis. Setelah membagi angket kepada guru selanjutnya melakukan wawancara untuk menggali lebih dalam secara personal. Wawancara dilakukan untuk menggali lebih dalam terkait kepraktisan perangkat pembelajaran Problem Posing Tipe Post Solution Posing. Penelitianini dilakukan secara bertahap dan berpeerosedur. Prosedur pelaksanaan penelitian yakni tahap perencanaan, tahap pelaksanaan, tahap penyelesaian.

\section{HASIL DAN PEMBAHASAN}

Penelitian ini bertujuan untuk mengetahui kepraktisan dari perangkat pembelajaran model Problem Posing Tipe Post Solution Posing. Hasil penelitian ini disajikan menjadi 2 bagian, yakni hasil angket dan wawancara.Instrumen yang digunakan untuk mengumpulkan data pada penelitian ini yaitu berupa angket. Sebelum melakuaka penelitian, instrumen yang akan digunakan di uji konstruk terlebih dahulu, yaitu uji validasi oleh dosen ahli pendidikan Matematika. Setelah angket di uji validasi oleh dosen ahli, maka diteruskan dengan uji coba instrumen. Jenis angket yang digunakan pada penelitian ini yaitu angket tertutup.

Perolehan hasil persentase yang diperoleh hasil dari angket menunjukan tingkat persetujuan terkait pernyataan yang ada pada angket. Jika persentasenya diperoleh $50 \%$ maka dapat dikatakan bahwa perangkat pembelajaran dalam hal ini RPP dan LKPD sangatlah praktis. Sebaliknya jika persentase di peroleh kurang dari 50\% maka dapat dikatakan bahwa perangkat pembelajaran dalam hal ini RPP dan LKPD tidak praktis. 
Dari hasil perhitungan angket yang sudah disebarkan kepada guru matematika di SMP Negeri 1 Batulayar, diperoleh persentase 78\% yang artinya guru tersebut setuju bahwa model Problem Posing Tipe Post Solution Posing sangat praktis. Perhitungn persentasi dihitung dengna menggunakan rumus pesentase $=$ (rata-rata skor) $/($ skor ideal $) \times 100 \%$. Dimana skor ideal di peroleh dari jumlah item pertanyaan angket dikali banyak pilihan jawaban.

\section{PENUTUP}

Berdasarkan hasil penelitian ini dapat disimpulkan bahwa perangkat pembelajaran Problem Posing Tipe Post Solution Posing sangatlah praktis. Hal ini dapat dilihat dari persentase perolehan angket yang di sebarkan kepada guru matematika di SMPN 1 Batulayar yaitu 78\% yang artinya guru setuju bahwa perangkat pembelajaran Problem Posing tipe Post Solution Posing sangat praktis. Dari hasil wawancara dengan guru matematika di SMPN 1 Batulayar berpendapat bahwa Problem Posing Tipe Post Solution Posing sangatlah praktis Karena tidak banyak mengeluarkan biaya dan bisa digunakan di semua materi tidak terpaku pada satu materi saja.

\section{REFERENSI}

Ruseffendi, E. T. (1980). Pengajaran Matematika Modern: Untuk Orang Tua Murid dan SPG. Tarsito.

Shoimin, A. (2014). 68 Model Pembelajaran Inovatif dalam Kurikulum 2013. Ar-Ruzz Media.

Suherman, E. (2003). Evaluasi Pembelajaran Matematika. JICA-UPI. 